\title{
Company Attributes and Stock Returns: A Comparative Study Between Selected Banks and Insurance Companies Listed on Dhaka Stock Exchange
}

\author{
Senjuti Barua \\ Lecturer, Department of Business Administration in Finance and Banking, Bangladesh University of \\ Professionals, Mirpur Cantonment, Dhaka-1216, Bangladesh
}

\begin{abstract}
This study focuses on four company attributes (firm beta, firm size, turnover by value, and volume of shares traded) that influence the stock returns of two separate industries- private commercial banks (PCBs) and insurance companies enlisted in Dhaka Stock Exchange (DSE), Bangladesh. Both of these industries have significant background to be considered in the empirical analysis while the stock returns of these selected companies being influenced by different attributes that exist in the Bangladesh stock market. This study integrates balanced panel data (in total 9,269 observations) including twenty-nine selected PCBs (3,692 observations) and forty-four selected insurance companies (5,577 observations) for the period from 2009 to 2019 . The findings of the panel data analysis reveal that out of the four independent variables incorporated into the panel data analysis, three of the firm attributes (firm size, turnover by value, and volume of shares traded) have significant impact on the stock returns of both the mentioned industries- PCBs and insurance companies. But the impact of firm Beta on the stock returns is significant in case of the stock returns of selected PCBs; whereas the impact of the same variable is insignificant in case of the stock returns of chosen insurance companies enlisted in DSE.
\end{abstract}

Keywords: Firm beta; firm size; turnover by value; volume of shares traded; private commercial banks; insurance companies

DOI: $10.7176 / \mathrm{RJFA} / 12-22-03$

Publication date: November $30^{\text {th }} 2021$

\section{Introduction}

Having numerous internal and external factors which affect the stock returns simultaneously, it has been difficult for the researchers to segregate the influence of each of these factors on the stock returns. But still researchers are interested in finding out the combination of variables that influences the stock returns most. This study focuses on four company attributes (firm beta, firm size, turnover by value, and volume of shares traded) which have been considered as explanatory variables to determine the stock returns. The analysis of the study aims at examining to what extent these four firm specific characteristics create variation in the stock returns of two separate industriesprivate commercial banks and insurance companies listed on DSE.

A previous study on DSE finds out how beta negatively influences the stock returns which contradicts with the concept of positive relation between beta and stock return described in the Capital Asset Pricing Model. This study also reveals significant influence of size, and volume of shares traded on the stock returns. It specifies that the findings of this study differ from the findings of developed markets; whereas those are identical to other evolving stock markets (Mobarek \& Mollah, 2005). Another empirical research on DSE incorporates Fama and French's three-factor model of CAPM which reveals that beta cannot be the only determinant of stock returns. It shows that there are other explanatory variables such as: book-to-market value, size, and the time effect which influence the stock return in a significant manner (Rahman \& Baten, 2006). To determine the 'size effect' on an emerging stock market such as Dhaka Stock Exchange, another study incorporates size related risk into the analysis that influences the stock returns of small and large firms (Chowdhury \& Shimon, A Closer Look at the Size Effect in the Dhaka Stock Exchange, 2008). A study investigates the influence of size, turnover by value or liquidity, and few other factors on the stock returns in DSE. This study focuses on finding out the reasons behind the negative relation between return and risk in Bangladesh stock market. Since the individual investors are not informed beforehand and there is lack of financial advisers, the market behaviour may not seem logical (Chowdhury \& Sharmin, Relevant Factors to Explain Cross-section of Expected Returns of the Firms Listed in the Dhaka Stock Exchange, 2013). Thus few of these previous studies on DSE explain how different company attributes influence the stock returns of the firms listed on DSE.

This study focuses on the stock returns of two separate industries (PCBs and insurance companies) on which the four company attributes have significant influences. Private commercial banks in Bangladesh have faced a considerable rise in non-performing loan (NPL) ratio from 2014 (4.98\%) to $2019(5.78 \%)$ which might result into liquidity crisis of the banks (Islam, 2020). Thus when both the central bank (Bangladesh Bank) and Bangladesh Securities and Exchange Commission (BSEC) impose different regulations to be followed within specific deadline, the stock returns of the banks get affected suddenly by possible liquidity crisis. It can also be mentioned that the 
stock market crash of 2010-11 also occurred due to such liquidity crisis of banks caused by sudden requirements on Statutory Liquidity Ratio (SLR) and Cash Reserve Ratio (CRR) imposed by Bangladesh Bank within a short deadline. On the other hand, another chosen industry of this study (insurance companies) has huge potential to grow in near future. Both the life insurance $(73.5 \%)$ and non-life insurances $(26.5 \%)$ of the insurance market of Bangladesh have considerable impact on the prospect and opportunities of this industry. The life insurance sector of Bangladesh is anticipated to grow by $6.45 \%$ within 2020 (PwC, 2019). Considering the prospect of this insurance sector and also the current scenario of PCBs of Bangladesh, these two separate industries have been chosen for the comparative analysis on the stock returns.

The hypothesis of the study is developed in the context of examining if firm beta, firm size, turnover by value, and volume of shares traded of the selected private commercial banks and insurance companies can influence their stock returns. The results of the study will explain i) which variables (Beta, MV, VA, and VO) have significant influence on the stock returns of the selected PCBs; ii) which variables (MV, VA, and VO) have significant influence on the stock returns of the selected insurance compnaies; and iii) which variable is insignificant (Beta) in case of selected insurance companies listed on DSE. These findings will add more value to the existing literature while supporting or contradicting with the previous research findings on the stock returns of DSE listed firms.

\section{Literature Review}

\subsection{Firm Beta and Stock Returns}

According to a pioneering study on the New York Stock Exchange for the time period from 1962 to 1980, a model has been applied to find out the linear function of beta and variance resulting into stock returns. This study reveals that the stocks that hold high beta perform better than those with low beta considering markets with upward trend; whereas stocks with high beta perform worse in markets having downward trend in comparison with the stocks that have low beta. This research analysis also examines that even if there is significant influence on the stock returns considering the aggregate market risk, the return of a particular security might not be only influenced by its systematic risk (Lakonishok \& Shapiro, 1984).

A study on the stock returns of UK (from 1960 to 1992) applies simple regression which discloses that there is a substantial positive influence of beta on the average stock returns (Strong \& Xu, 1997). Another study on five Pacific-Basin emerging markets reveals that market beta has weak influence over the stock returns of all of these five markets (Chui \& Wei, 1998). A panel data analysis on the stock returns of the Kuala Lumpur Stock Exchange for the period 1993-2000 discloses that beta effects the stock returns in a substantial positive manner (Pandey, 2001). Another study on the non-financial companies enlisted in the Stock Exchange of Singapore and the Kuala Lumpur Stock Exchange examines that beta has positive influence over stock returns when the returns are increasing in an upward direction. However, beta has negative effect over stock returns when the returns are decreasing in a downward direction (Lau, Lee, \& McInish, 2002).

A multifactor asset pricing model of Fama and French (1996) is applied on the stock returns of few selected markets which indicates that beta is not the only risk measure to influence the stock returns of these markets. So this study contradicts with the concept of Capital Asset Pricing Model (CAPM) which assumes that beta alone can define the stock returns (Drew \& Veeraraghavan, 2003). Another study on Tehran Stock Exchange also explains that beta alone cannot predict stock returns. It also reveals that the portfolios which have higher beta acquire higher returns while being compared to those having lower beta (Rahmani, Sheri, \& Tajvidi, 2006). In line with this research, another research on the stock returns of India applies multifactor model which explains that beta cannot be the only risk measure rather risk should be considered in a multidimensional context (Singh, 2009). This contradiction with the concept of CAPM is also seen in another study held on Romanian Stock Market (Tudor, 2008). Regardless of the fact that some of the studies do not support the concept of CAPM, many of the other studies examine a substantial relationship observed between beta and stock returns (Chambers, Sezgin, \& Karaaslan, 2013).

\subsection{Firm Size and Stock Returns}

One of the empirical studies on New York Stock Exchange reveals that higher returns are acquired by smaller firms compared to those of larger firms (BANZ, 1981). Another study on the same market investigates that size is the only substantial variable for the period 1962-1980 while being compared to the other variables used in the study such as beta and variance (Lakonishok \& Shapiro, 1984). With the application of Fama-MacBeth regression, another study on New York Stock Exchange reveals that the impact of size is more significant than that of beta (Fama \& French, 1992). Through the application of simple regression, it is found that firm size has substantial negative influence over the stock returns of UK (Strong \& Xu, 1997). Another study reveals the size effect on the stock returns of five emerging markets. It illustrates that size effect is noteworthy in all of these selected markets except in that of Taiwan (Chui \& Wei, 1998).

A study on the Malaysian stock market applies panel data analysis which mentions firm size as the most substantial determinant of stock returns compared to other determinants such as: beta, book-to-market ratio, 
earnings-price ratio and dividend yield (Pandey, 2001). Another study on Budapest Stock Exchange also supports that size effect is very significant on the stock returns' distribution (LUKÁCS, 2002). A negative size effect exists on the stock returns of the markets of Singapore and Malaysia (Lau, Lee, \& McInish, 2002). Another study on few emerging markets also supports the significant contribution of firm size on the variation of stock returns (Drew \& Veeraraghavan, 2003). Its significant contribution is also supported in the studies conducted on Indian stock market with the application of multivariate analysis (Singh, 2009) (Kumar \& Sehgal, 2004). A study on Bucharest stock exchange for the period 2002-2008 also indicates how persistent the size effect is on the stock returns (Tudor, 2008). Another study on German stock market figures out whether there is any simultaneity bias in previous studies while considering the influences occurred by firm size on the stock returns (Amel-Zadeh, 2010).

Panel data analysis is applied for determining the significant effect of different variables which reveals that firm size positively effects the changes in the stock returns of Nigerian stock market (Olowoniyi \& Ojenike, 2012). On the other hand, through the application of Fama-MacBeth (1973) procedure, it is found that there is no significant impact of firm size on the stock returns of selected firms enlisted in Colombo Stock Exchange for the period 2005-2010 (Shafana, Rimziya, \& Jariya, 2013). Another empirical analysis indicates the significant contribution of firm size on the changes of stock returns of 307 non-financial firms enlisted in Karachi Stock Exchange (Tahir, Sabir, Alam, \& Ismail, 2013). The significant positive contribution of firm size on the stock returns is also analyzed in other studies on Karachi Stock Exchange which apply panel data method indicating the effectiveness of fixed effect regression (Mahmood \& Waheed, 2014).

A study on Bahrain Stock Exchange also examines the significant influence occurred by firm size on the stock returns while incorporating three different estimations of panel data analysis- OLS regression, fixed effects and random effects regression (Sharif, Purohit, \& Pillai, 2015). But insignificant negative influence of firm size is also investigated in another study on Nigerian Stock Exchange that applies panel data regression for conducting empirical analysis (Ayuba, Balago, \& Dagwom, 2018). On the other hand, another study on Nigerian Stock Exchange reveals the significant positive influence of firm size on stock returns while incorporating panel data method (Akwe \& Garba, 2019).

\subsection{Turnover by value and Stock Returns}

Turnover by value represents the volume of shares that are executed over a specific period of time in terms of the home currency. A study on 100 nonfinancial firms enlisted in the Karachi Stock Exchange incorporates a generalized method of moments (GMM) while using panel data from 2006 to 2010 . This study reveals that liquidity is a significant determinant of stock returns while having a negative influence over the stock returns of these selected firms (Ahmad, Fida, \& Zakaria, 2013). Another study on the New Zealand stock market investigates whether any particular listed firm acquires any return premium for their stocks having lower or higher liquidity risk (Nguyen \& Lo, 2013).

\subsection{Volume of shares traded and Stock Returns}

Volume of shares traded represents the total number of shares that are transacted over a specific period of time. A study on the NASDAQ firms applies OLS estimation which combines the results with different explanatory variables. This study reveals that the firms with small size or market value face a decline in their volume whereas the firms with large size or market value face an increase in the volume (G.S. Maddala, 1995). Another study on the Shanghai Stock Exchange applies panel data regression which suggests the fixed-effects regression to be more effective incorporating 100 listed firms in this stock market for the period 2002-2007. This study reveals that volume of shares transacted has significant positive influence over stock returns in both the cases of the market while facing upward trend and downward trend (Pan, 2012).

\section{Research Methodology}

The empirical analysis of this study is based on panel dataset that includes four selected firm attributes of listed 29 PCBs and 44 insurance companies of DSE for the period 2009-2019. This dataset has been collected from Thomson Reuters DataStream. The empirical analysis using this dataset is conducted through STATA.

These firms from two separate industries have been selected for separate reasons. The stock returns of PCBs get mostly affected whenever there is any stock price decline in the DSE Index. This banking industry is also facing the increasing percentage of nonperforming loans in the recent period. On the other hand, Bangladesh is facing huge challenges occurred by the natural disasters throughout the year as well as the challenges coming from individual background. So this insurance industry has great prospect in the coming days to utilize the opportunities to enhance the potential growth of the industry. All of these 29 PCBs and 44 insurance companies have been chosen because the dataset on the mentioned independent variables are available for the chosen period 2009-2019. Panel regression is applied for the analysis along with robustness tests to elaborate the possibility of heteroskedasticity and multicollinearity problem in the dataset. 
Table 3.1: Measurements of variables

\begin{tabular}{|c|c|c|c|}
\hline Variables & Measurements & $\begin{array}{l}\text { Expected } \\
\text { Sign }\end{array}$ & Reference \\
\hline LN SR & $\begin{array}{l}\quad \text { LN SR = Natural logarithm } \\
\qquad \quad\left(\mathrm{TRI}_{\mathrm{t}} / \mathrm{TRI}_{(\mathrm{t}-1)}\right) \\
\text { Here, } \mathrm{TRI}_{\mathrm{t}}=\text { total stock return } \\
\text { index at month } \mathrm{t} \text {; and } \\
\mathrm{TRI}_{(\mathrm{t}-1)}=\text { total stock return index } \\
\text { at previous month }(\mathrm{t}-1)\end{array}$ & $\begin{array}{l}\text { Not } \\
\text { Applicable }\end{array}$ & \\
\hline Beta & $\begin{array}{l}\text { Slope amid the excess return } \\
\text { from a particular stock's total } \\
\text { return index and the excess } \\
\text { return from its Value Weighted } \\
\text { Index }\end{array}$ & $+/-$ & $\begin{array}{l}\text { (Strong \& Xu, 1997), (Pandey, 2001), (Lau, Lee, } \\
\& \text { McInish, 2002), (Drew \& Veeraraghavan, } \\
\text { 2003), (Rahmani, Sheri, \& Tajvidi, 2006), } \\
\text { (Tudor, 2008), (Chambers, Sezgin, \& Karaaslan, } \\
\text { 2013), (Barua, 2020) }\end{array}$ \\
\hline MV & $\begin{array}{l}\text { Market value of a firm }=\text { Market } \\
\text { price per share* Total number of } \\
\text { shares outstanding }\end{array}$ & $+/-$ & $\begin{array}{l}\text { (BANZ, 1981), (Strong \& Xu, 1997), } \\
\text { (LUKÁCS, 2002), (Lau, Lee, \& McInish, 2002), } \\
\text { (Drew \& Veeraraghavan, 2003), (Olowoniyi \& } \\
\text { Ojenike, 2012), (Shafana, Rimziya, \& Jariya, } \\
\text { 2013), (Ayuba, Balago, \& Dagwom, 2018) }\end{array}$ \\
\hline VA & $\begin{array}{l}\text { Turnover by value per month in } \\
\text { BDT }\end{array}$ & + & $\begin{array}{l}\text { (Ahmad, Fida, \& Zakaria, 2013), (Nguyen \& Lo, } \\
\text { 2013), (Barua, 2020) }\end{array}$ \\
\hline $\mathrm{VO}$ & $\begin{array}{l}\text { Total number of shares that are } \\
\text { traded per month }\end{array}$ & + & (Pan, 2012), (Barua, 2020) \\
\hline
\end{tabular}

Note: Monthly data has been collected for all the above mentioned variables

Table 3.1 illustrates how the independent and dependent variables are defined and measured and which references these variables follow to be analyzed effectively.

Fixed-effects and random-effects regression are used while conducting the panel data analysis. To differentiate among these assumptions, Hausman Specification Test and Breusch-Pagan Lagrangian Multiplier (LM) Test are incorporated. These tests indicate the better effectiveness of fixed-effects estimation compared to random-effects estimation. The following regression model is specified for both the cases of banking and insurance industry to determine the influence of the selected firm attributes on the stock returns of these chosen firms listed in DSE:

$$
\mathrm{LN} \mathrm{SR}=\beta_{0}+\beta_{1} * \mathrm{BETA}_{\mathrm{it}}+\beta_{2} * \mathrm{MV}_{\mathrm{it}}+\beta_{3} * \mathrm{VA}_{\mathrm{it}}+\beta_{4} * \mathrm{VO}_{\mathrm{it}}+€_{\mathrm{it}}
$$

Where, subscript (i): symbolizes the cross-section dimension;

$(\mathrm{t})$ : symbolizes the time series effect

$\left(€_{\mathrm{it}}\right)$ : symbolizes the error term

\section{Result}

\subsection{Analysis of the Study:}

Table no. 4.1 shows the descriptive statistics of the dependent and independent variables that have been incorporated into the analysis.

Table no 4.1: Descriptive Statistics of the Variables (PCBs)

\begin{tabular}{|l|c|c|c|c|c|}
\hline Variables & No. of Observations & Mean & Std. Dev. & Minimum & Maximum \\
\hline LN SR & 3,712 & .020 & .653 & -18.538 & 16.496 \\
\hline Beta & 3,712 & 1.025 & .487 & -.468 & 6.979 \\
\hline MV & 3,712 & 17312.73 & 12198.06 & 317.12 & 94329.56 \\
\hline VA & 3,692 & $2.11 \mathrm{e}+09$ & $8.11 \mathrm{e}+09$ & 131 & $1.26 \mathrm{e}+11$ \\
\hline VO & 3,692 & 40412.02 & 67233.35 & 68.769 & 924735.5 \\
\hline
\end{tabular}

Source: Author's Calculation, 2021

The above table 4.1 represents the mean value of the stock return (LN SR) as .020 during the chosen time period which has a minimum value of -18.538 and a maximum value of 16.496 . This negative minimum value illustrates how the stock returns faced a major decline as a result of the 2009-10 stock market crash in Bangladesh. 
Table no 4.2: Descriptive Statistics of the Variables (Insurance Companies)

\begin{tabular}{|l|c|c|c|c|c|}
\hline Variables & No. of Observations & Mean & Std. Dev. & Minimum & Maximum \\
\hline LN SR & 5,577 & .0297 & .677 & -10.400 & 7.875 \\
\hline Beta & 5,577 & 1.01 & .471 & -.708 & 6.012 \\
\hline MV & 5,577 & 2188.131 & 3008.928 & .17 & 29511.88 \\
\hline VA & 5,582 & $7.72 \mathrm{e}+08$ & $5.47 \mathrm{e}+09$ & 16.333 & $2.07 \mathrm{e}+11$ \\
\hline VO & 5,582 & 4235.676 & 6965.188 & 3.525 & 99001.01 \\
\hline
\end{tabular}

Source: Author's Calculation, 2021

Table 4.2 displays the stock return's mean, minimum and maximum value of $.0297,-10.400$ and 7.875 respectively. From both the table 5.1 and table 5.2, it can be seen that the stock returns of selected PCBs faced a minimum value of -18.538; whereas the stock returns of selected insurance companies faced the same as -10.400 . This difference in the minimum value of stock returns from two separate industries represents that the shareholders lost approximately $18.5 \%$ of their stock returns from PCBs. On the other hand, the same shareholders lost almost $10.4 \%$ of their stock returns from insurance companies.

In addition to this variation in terms of stock returns, the variation in terms of market value and volume of shares transacted is also substantial. The mean market value of selected PCBs (17312.73) is much higher than that of selected insurance companies (2188.131). On the other hand, the mean volume of shares traded of selected PCBs (40412.02) is also much higher than that of selected insurance companies (4235.676). These values indicate that despite having higher mean value of firm size and traded volume of shares than those of insurance companies, PCBs faced comparatively a major decline in their stock returns (18.5\%) than insurance companies $(10.4 \%)$.

Table no 4.3: Pearson Correlation Matrices for Dependent and Independent Variables (PCBs)

\begin{tabular}{|l|c|c|c|c|c|}
\hline Variables & LN SR & Beta & MV & VO & VA \\
\hline LN SR & 1.000 & & & & \\
\hline Beta & -0.026 & 1.000 & & & \\
\hline MV & -0.077 & -0.070 & 1.000 & & \\
\hline VA & 0.045 & 0.075 & -0.026 & 1.000 & \\
\hline VO & 0.237 & 0.055 & 0.104 & 0.028 & 1.000 \\
\hline
\end{tabular}

Source: Author's Calculation, 2021

Table 4.3 reveals the degree to which the dependent and independent variables are correlated from the perspective of selected PCBs. According to the matrix, firm beta and firm size have negative correlation with stock return. This indicates that the more the firm beta and firm size, the less the stock return. On the other hand, turnover by value and traded volume of shares over a specific period have positive correlation with stock returns of PCBs. Table no 4.4: Pearson Correlation Matrices for Dependent and Independent Variables (Insurance Companies)

\begin{tabular}{|l|c|c|c|c|c|}
\hline Variables & LN SR & Beta & MV & VO & VA \\
\hline LN SR & 1.000 & & & & \\
\hline Beta & 0.077 & 1.000 & & & \\
\hline MV & -0.043 & -0.022 & 1.000 & & \\
\hline VA & 0.021 & 0.050 & 0.328 & 1.000 & \\
\hline VO & 0.305 & 0.202 & -0.020 & 0.035 & 1.000 \\
\hline
\end{tabular}

Source: Author's Calculation, 2021

Table 4.4 reveals the extent to which the variables are correlated from the perspective of selected insurance companies. Firm beta is positively associated with stock returns in terms of insurance companies whereas this correlation is negative in case of PCBs. This is a considerable difference among the correlations that exist in case of PCBs and insurance companies. But considering the correlation of firm size with stock returns of PCBs and insurance companies, there is negative association in both the cases. In addition to this, in both the cases, VA and VO have significant positive association with the stock returns of two separate industries. Apart from the consideration of the extent to which independent variables are associated with dependent variable, there is also other correlation to be considered among different independent variables themselves. This consideration will assist in identifying whether there is any multicollinearity problem or not.

To detect such problem related to heteroskedasticity or multicollinearity, few robustness tests have been shown for the stock returns of both the selected industries- PCBs and insurance companies. 
Table no 4.5: Summary of Robustness Tests

\begin{tabular}{|l|c|c|c|c|}
\hline \multirow{2}{*}{ Tests } & \multicolumn{2}{c|}{ Private Commercial Banks } & \multicolumn{2}{c|}{ Insurance Companies } \\
\cline { 2 - 5 } & Statistics & $\mathrm{p}$-value & Statistics & $\mathrm{p}$-value \\
\hline Modified Wald Test (Chi-square) & 1072.24 & 0.000 & 121.41 & 0.000 \\
\hline Mean Variance Inflation Factors & 1.01 & - & 1.08 & - \\
\hline Hausman Specification Test (Chi-square) & 29.60 & 0.000 & 218.27 & 0.000 \\
\hline Lagrangian Multiplier Test (Chi-square) & 0.00 & 1.000 & 0.00 & 1.000 \\
\hline
\end{tabular}

Source: Author's Calculation, 2021

As mentioned in the above table 4.5, the Chi-square value (1072.24) and the p-value (0.000) from Modified Wald Test indicate the existence of heteroskedasticity in the data of PCBs. On the other hand, the Chi-square value (121.41) and the p-value (0.000) from the same test shows the same result in the data of selected insurance companies. To minimize the possible biasness in the standard errors for this heteroskedasticity problem, robust option has been incorporated into the regression. This regression with robust option reveals that there is no significant change in the coefficient values. Variance Inflation Factors (VIF) test is conducted to identify whether there is any multicollinearity problem or not. The mean VIF value for PCBs (1.01) and insurance companies (1.08) indicate that there is no presence of multicollinearity problem among the independent variables; because in both the cases the mean VIF value is consistently less than 2.

In case of panel dataset, there might be some error arisen from any particular company's unique characteristics influencing its stock price. To control any biasness occurred due to its influence on the dependent or independent variables, some specific methods are to be used. Here, both the fixed-effect and random-effect regression have been conducted. The Chi-sq. value (29.60 and 218.27) and p-value (0.000 and 0.000) from the Hausman Specification Test in both the cases of PCBs and insurance companies reveal that fixed-effect regression is more appropriate than random-effect regression in each of the cases of two separate industries. This outcome is also supported by the outcome from Lagrangian Multiplier Test having a Chi-sq. value of 0.00 and a p-value of 1.000.

The results of the Fixed Effect regression model is exhibited on the table 4.6 below:

Table no 4.6: Panel Regression (Fixed Effect Model)

\begin{tabular}{|l|c|c|c|c|}
\hline \multicolumn{1}{|c|}{ Variables } & Private Commercial Banks & \multicolumn{2}{c|}{ Insurance Companies } \\
\hline Constant & Coefficients & p-value & Coefficients & p-value \\
\hline Beta & .154 & 0.032 & .019 & 0.727 \\
\hline MV & -.073 & $0.000^{* * *}$ & .049 & 0.211 \\
\hline VA & -.0000107 & $0.016^{* *}$ & -.0000856 & $0.000^{* * *}$ \\
\hline VO & $3.37 \mathrm{e}-12$ & $0.000^{* * *}$ & $8.97 \mathrm{e}-12$ & $0.005^{* * *}$ \\
\hline $\mathrm{R}^{2}$ & $2.90 \mathrm{e}-06$ & $0.000^{* * *}$ & .0000335 & $0.000^{* * *}$ \\
\hline Adj. ${ }^{2}$ & 0.071 & - & 0.095 & - \\
\hline F-stat & 0.070 & - & 0.094 & - \\
\hline Number of observations & 2.83 & $0.000^{* * *}$ & 4.90 & $0.000^{* * *}$ \\
\hline Number of groups & \multicolumn{2}{|c|}{3,692} \\
\hline
\end{tabular}

Note: $* * * * *$ denotes statistical significance at the $1 \%$, and $5 \%$ level, respectively

Source: Author's Calculation, 2021

According to table 4.6, the regression line of the natural logarithm of stock return of PCBs and selected insurance companies can be anticipated. Comparing these two results based on p-value, it can be seen that in both the cases, VA and VO have significant positive influence on the stock returns at $1 \%$ significance level. It indicates that the more the VA and VO, the more the stock returns of the two chosen industries. In addition to this, MV is negatively related to the stock returns in both the cases; indicating that when MV increases, stock returns decrease for both PCBs and insurance companies. But the negative influence of MV on the stock returns of PCBs and insurance companies is significant at $5 \%$ and $1 \%$ significance level respectively. Another company attribute Beta has significant negative influence on the stock returns of PCBs at $1 \%$ significance level. But the same attribute has insignificant positive influence on the stock returns of chosen insurance companies.

The value (0.071) of coefficient of determination indicates that $7.10 \%$ of the stock return discrepancy amongst chosen PCBs can be elaborated by the four selected company attributes. In case of insurance companies, this value (0.095) reveals that the same mentioned firm characteristics depict $9.50 \%$ of stock return changes occurred in selected insurance companies listed on DSE. The other explanatory attributes that have not been considered in this model and the error term can influence the remaining percentage in both the cases. The fitness of the model in case of PCBs and insurance companies is defined by F-value of 2.83 (p-value 0.000) and 4.90 (p-value 0.000) respectively. 


\section{Discussion}

\subsection{Firm Beta and Stock Returns:}

Firm beta in case of selected PCBs and insurance companies has a coefficient value of -.073 and .049 along with p-value of 0.000 and 0.211 respectively. These values indicate that firm beta has substantial negative influence on stock returns of PCBs at 1\% significance level; whereas the positive effect of firm beta is insignificant in case of stock returns of chosen insurance companies enlisted in DSE. The outcome in case of PCBs is supported by the findings of a study on the market of Singapore and Malaysia (Lau, Lee, \& McInish, 2002). On the other hand, the outcome in case of insurance companies is supported by the findings from the studies on different markets (Lakonishok \& Shapiro, 1984), (Chui \& Wei, 1998), (Tudor, 2008), and (Singh, 2009). So these findings of the study on DSE reveal that the influence of systematic risk can be significant and insignificant at the same time in case of two separate industries- PCBs and insurance companies respectively.

\subsection{Firm Size and Stock Returns:}

The coefficient values of firm size in case of selected PCBs and insurance companies are -.0000107 and -.0000856 (p-value of 0.016 and 0.000 respectively). The mentioned values represent significant negative influence of firm size on the stock returns of both the chosen industries- PCBs and insurance companies at $5 \%$ and $1 \%$ significance level respectively. These outcomes are supported by the findings of studies conducted on the stock returns of New York Stock Exchange, UK, Singapore and Malaysia (BANZ, 1981), (Strong \& Xu, 1997), and (Lau, Lee, \& McInish, 2002). But this is contradicted by the results of those studies that reveal the substantial positive influence of firm size on stock returns (Olowoniyi \& Ojenike, 2012), (Mahmood \& Waheed, 2014), and (Akwe \& Garba, 2019). A study on New York Stock Exchange also discloses that the effect of firm size is more significant than that of firm beta (Fama \& French, 1992).

\subsection{Turnover by value and Stock Returns:}

This variable has coefficient values of $3.37 \mathrm{e}-12$ and $8.97 \mathrm{e}-12$ in case of selected PCBs and insurance companies along with p-value of 0.000 and 0.005 respectively. The mentioned determinant has substantial positive influence on the stock returns of both the chosen PCBs and insurance companies at $1 \%$ significance level. This variable is also considered as liquidity proxy. This outcome of the study is contradicted by the finding of a study conducted on Karachi Stock Exchange which finds out a significant negative influence on the stock returns (Ahmad, Fida, \& Zakaria, 2013).

\subsection{Volume of shares traded and Stock Returns:}

The coefficient values of VO in case of selected PCBs and insurance companies are 2.90e-06 and .0000335 (pvalue of 0.000 and 0.000 respectively). The mentioned values indicate that this variable has significant positive influence on the stock returns of both the selected industries at 1\% significance level. This is supported by another study conducted on Shanghai Stock Exchange (Pan, 2012).

Considering all of these findings, it can be concluded that three (Beta, VA, and VO) amongst the four firm characteristics (Beta, MV, VA, and VO) are significant characteristics of the stock returns of chosen PCBs at $1 \%$ significance level; whereas the influence of MV is significant at 5\% significance level. On the other hand, out of these four variables, three of the chosen firm characteristics (MV, VA, and VO) are significant characteristics of the stock returns of chosen insurance companies at $1 \%$ significance level. This indicates that systematic risk (Beta) is insignificant in case of the returns from insurance companies; whereas that risk is significant in case of the returns from PCBs (at 1\% significance level). The fitness of model also reveals that the selected explanatory variables have statistically significant effect on the stock returns in both the cases (at $1 \%$ significance level). So these four firm specific characteristics of PCBs and insurance companies are statistically significant enough to justify the fitness of the model.

\section{Limitations of Analysis}

One of the considerable limitations of the analysis of the study is that more firm specific characteristics in terms of explanatory variables could be integrated into the panel data analysis to examine how these attributes create variations in the stock returns of the chosen PCBs and insurance companies. But due to lack of available consistent data on more company attributes for the period 2009-2019, this study faced such limitation.

\section{Conclusion and Recommendation}

The study reveals that two of the chosen company attributes- turnover by value and volume of shares traded have substantial positive impact on the stock returns of both the chosen PCBs and insurance companies; whereas firm size effects the stock returns of both the industries in a negative pattern. But in terms of firm beta, its negative influence on the stock returns of PCBs is significant; whereas the positive influence of firm beta on the chosen insurance companies' stock returns is insignificant. Thus the comparative study reveals the differences occurred 
by the explanatory variables on the stock returns of two separate industries in Dhaka Stock Exchange, Bangladesh. Both the industries and the mentioned four determinants have to be considered by the potential investors while investing in this emerging stock market. Since the limitation of the study indicates that some other explanatory variables should be incorporated into the analysis, further researches can be conducted to identify other significant firm attributes that have major influence on the stock returns of these chosen industries of Bangladesh.

\section{References}

Ahmad, H., Fida, B. A., \& Zakaria, M. (2013). The Co-determinants of Capital Structure and Stock Returns: Evidence from the Karachi Stock Exchange. The Lahore Journal of Economics, 18(1), 81-92.

Akwe, J. A., \& Garba, S. B. (2019). Effects of Internal and External Factors on Stock Returns of Large Size Firms in Nigeria. Global Journal of Accounting, 5(1), 44-56.

Amel-Zadeh, A. (2010). The Return of the Size Anomaly: Evidence from the German Stock Market. European Financial Management, 17(1), 145-182.

Ayuba, A. J., Balago, G. S., \& Dagwom, D. Y. (2018). Effects of Firm Level Attributes on Stock Returns in Nigeria. International Journal of Finance and Accounting, 7(4), 122-131.

BANZ, R. W. (1981). The Relationship Between Return and Market Value of Common Stocks. Journal of Financial Economics, 9, 3-18.

Barua, S. (2020). Firm Level Characteristics and Stock Returns: Evidence from Selected Insurance Companies Listed on the Dhaka Stock Exchange. Asian Economic and Financial Review, 10(12), 1356-1365.

Chambers, N., Sezgin, F. H., \& Karaaslan, B. (2013). An Analysis of the Effects of Capital Structure and the Beta Coefficient on Stock Returns: A Case Study of the Istanbul Stock Exchange (ISE) - Manufacturing Industry. International Journal of Business and Social Science, 4(7), 279-290.

Chowdhury, S. S., \& Sharmin, R. (2013). Relevant Factors to Explain Cross-section of Expected Returns of the Firms Listed in the Dhaka Stock Exchange. International Business Research, 6(3), 165-173.

Chowdhury, S. S., \& Shimon, Z. A. (2008, July). A Closer Look at the Size Effect in the Dhaka Stock Exchange. Independent Business Review, 1(2), 42-53.

Chui, A. C., \& Wei, K. J. (1998). Book-to-market, firm size, and the turn-of-the-year effect: Evidence from PacificBasin emerging markets. Pacific-Basin Finance Journal, 6, 275-293.

Drew, M. E., \& Veeraraghavan, M. (2003). Beta, Firm Size, Book-To-Market Equity And Stock Returns- Further evidence from emerging markets. Journal of the Asia Pacific Economy, 8(3), 354-379.

Fama, E. F., \& French, K. R. (1992). The Cross-Section of Expected Stock Returns. THE JOURNAL OF FINANCE, 427-265.

G.S. Maddala, M. N. (1995). An unobserved component panel data model to study the effect of earnings surprises on stock prices, trading volumes, and spreads. Journal of Econometrics, 229-242.

Islam, T. (2020, July 21). NPL and its impact on the banking sector of Bangladesh. Dhaka, Bangladesh: The Financial Express. Retrieved from https://www.thefinancialexpress.com.bd/views/npl-and-its-impact-on-thebanking-sector-of-bangladesh-1595343188

Kumar, M., \& Sehgal, S. (2004). Company Characteristics and Common Stock Returns : The Indian Experience. The Journal of Business Perspective, 33-45.

Lakonishok, J., \& Shapiro, A. C. (1984, Jul. - Aug.). Stock Returns, Beta, Variance and Size: An Empirical Analysis. Financial Analysts Journal, 40(4), 36-41.

Lau, S. T., Lee, C. T., \& McInish, T. H. (2002). Stock returns and beta, firms size, E/P, CF/P, book-to-market, and sales growth: evidence from Singapore and Malaysia. Journal of Multinational Financial Management, 12, 207-222.

LUKÁCS, P. (2002). STOCK RETURN DISTRIBUTION AND MARKET CAPITALISATION. Hungarian Statistical Review, 138-148.

Mahmood, H., \& Waheed, A. (2014). Relationship Between Price/Earning, Dividend Yield, Size and Stock Returns of Listed Pakistani Firms. Journal of Basic and Applied Scientific Research, 4(10), 83-90.

Mobarek, A., \& Mollah, A. S. (2005, December). The General Determinants of Share Returns: An Empirical Investigation on the Dhaka Stock Exchange. Review of Pacific Basin Financial Markets and Policies, 593612. doi:10.1142/S0219091505000518

Nguyen, N. H., \& Lo, K. H. (2013). Asset returns and liquidity effects: Evidence from a developed but small market. Pacific-Basin Finance Journal, 21, 1175-1190.

Olowoniyi, A., \& Ojenike, J. (2012, Aug.). Determinants of stock return of Nigerian-listed firms. Journal of Emerging Trends in Economics and Management Sciences, 3(4), 389 - 392.

Pan, L. (2012). Which Factors Explain Stock Returns on the Shanghai Stock Exchange Market? A Panel Data Analysis of a Young Stock Market. Stockholm, Sweden: KTH Industrial Engineering and Management.

Pandey, I. M. (2001). The Expected Stock Returns of Malaysian Firms: A Panel Data Analysis. SSRN Electronic Journal, 1-26. 
PwC. (2019). Potential for growth: Transforming Bangladesh's insurance sector. Dhaka: PricewaterhouseCoopers Bangladesh Private Limited. Retrieved from https://www.pwc.com/bd/en/assets/pdfs/research-insights/2019/potential-for-growth.pdf

Rahman, M. M., \& Baten, M. A. (2006, October). An Empirical Testing of Capital Asset Pricing Model in Bangladesh. Journal of Research (Science), 17(4), 225-234.

Rahmani, A., Sheri, S., \& Tajvidi, E. (2006, November 28). Accounting Variables, Market Variables and Stock Return in Emerging Markets: Case of Iran.

Shafana, M., Rimziya, A. F., \& Jariya, A. I. (2013, Apr.). Relationship between Stock Returns and Firm Size, and Book-To-Market Equity: Empirical Evidence from Selected Companies Listed on Milanka Price Index in Colombo Stock Exchange. Journal of Emerging Trends in Economics \& Management Sciences, 4(2), 217.

Sharif, T., Purohit, H., \& Pillai, R. (2015). Analysis of Factors Affecting Share Prices: The Case of Bahrain Stock Exchange. International Journal of Economics and Finance, 7(3), 207-216.

Singh, R. (2009). Company Attributes and Stock Returns in India: A Panel Data Analysis.

Strong, N., \& Xu, X. G. (1997). Explaining the Cross-Section of UK Expected Stock Returns. British Accounting Review, 29, 1-23.

Tahir, S. H., Sabir, H. M., Alam, T., \& Ismail, A. (2013). IMPACT OF FIRM'S CHARACTERISTICS ON STOCK RETURN: A CASE OF NON-FINANCIAL LISTED COMPANIES IN PAKISTAN. Asian Economic and Financial Review, 3(1), 51-61.

Tudor, C. (2008). Firm-specific factors as predictors of future returns for Romanian common stocks: empirical evidence. Recent Researches in Business Administration, Finance and Product Management, 73-78. 